Nutr. Metabol. 1972;14:I-VIII

\title{
Contents, Vol. 14, 1972
}

\section{Nutrition and Metabolism}

Journal of Nutrition, Metabolic Diseases and Dietetics

Main Editor N.Zöllner, München Associate Editor C. Wolfram, München

Editorial Board

W. Auerswald, Wien

E. Le Breton, Paris

H.-D. Cremer, Giessen

F. Falkner, Yellow Springs, Ohio

F. Fidanza, Perugia

R. GITZELMANN, Zurich

G.Hartmann, Bern K.Hellström, Stockholm C.Den Hartog, Den Haag B. Hess, Dortmund

B.Jacotot, Créteil H.Kapp, Basel H. K. Mangold, Münster R. Nicolaysen, Oslo T.R.E.Pilkington, London P. Roine, Helsinki E.Rossi, Bern H. Sarles, Marseille

G. Schlierf, Heidelberg

J. C. Somogyi, Zurich

J.Trémolières, Paris

A.J.Vergroesen, Vlaardingen

A.Wretlind, Stockholm

J.F.De Wijn, Zeist

$\mathrm{S}^{7} / 8 / 8 \mathrm{~S}$ Sii

S. Karger $\cdot$ Basel $\bullet$ München $\bullet$ Paris $\bullet$ London $\cdot$ New York $\cdot$ Sydney

S. Karger · Basel · München · Paris · London · New York · Sydney Arnold-Böcklin-Strasse 25, CH-4000 Basel 11 (Switzerland)

All rights, including that of translation into other languages, reserved. Photomechanic

reproduction (photocopy, microcopy) of this book or parts thereof without special permission of the publishers is prohibited.

(C) Copyright 1972 bei S.Karger AG, Verlagfür Medizin und Naturwissenschaften, Basel Printed in Switzerland by Lüdin AG, Liestal

Index

Abdellatif, A. M. M.; Starrenburg, Anna, and Vles, R.O.: Effects of Hardened

Palm Oil and Protein on the Pathological and Hematological Charac

teristics of Ducklings Fed Rapeseed Oil

17

Andersen, H.T. and Stavem, P.: Iron Deficiency Anaemia and the Acid-Base

Variations of Exercise 129

Anderson, T.A.; Kim, I., and Fomon, S.J.: Iron Status of Anemic Rats Fed Iron-

Fortified Cereal-Milk Diets 355

Bach, A.; Guisard, D.; Metais, P., and Debry, G.: Metabolic Effects Following a

Short and Medium Chain Triglycerides Load in Dogs. III. Infusion of

Trinonanoate 203 
Berg, K.: Body Composition and Nutrition of Adolescent Boys Training for Bicycle Racing 172

Bigard, M.A.: vide Guisard, D.

Birchwood, B.: Serum Lipids and Lipoprotein Following Acute Myocardial Infarction in Women 38

Bruckdorfer, K.R.; Kari-Kari, B.P.B.; Khan, I.H., and Yudkin, J.: Activity of Lipogenic Enzymes and Plasma Triglyceride Levels in the Rat and the Chicken as Determined by the Nature of the Dietary Fat and Dietary

Carbohydrate 228

Chandrasekharan, N.: Effect of Prolonged Starvation and Subsequent Realimentation on Serum Proteins 181

Coles, Betty L. and MacDonald, I.: The Influence of Dietary Protein on Dietary

Carbohydrate: Lipid Interrelationships 238

Debry, G.: vide Bach, A.

Debry, G.: vide Guisard, D.

Debry, G.: vide Poullain, B.

Edgren, B. and Hellström, K.: In vivo Studies of the Metabolism of Mevalonic

Acid in Nephrotic Rats 331

Ferro-Luzzi, Anna ; Migliaccio, P. A.; Sorrentino, Donatella, and Mariani, A.: Studies on Intermittent Supplementation. Effect of Supplementation of Gluten with Casein Every Second or Third Day on Growing Rats Fed High-Protein Diets 159

Fomon, S.J.: vide Anderson, T. A.

Forsum, Elisabeth and Hambraeus, L.: Biological Evaluation of A Whey Protein Fraction, with Special Reference to its Use as a Phenylalanine-Low

Protein Source in the Dietary Treatment of PKU 48

Fry, A. J.: The Effect of a 'Sucrose-Free' Diet on Oral Glucose Tolerance in Man 313

Gennes, J. L. De; Thomopoulos, P.; Truffert, J. et Labrousse De Tregomain, B.:

Hyperlipémies dépendantes de Talcool 141

Gertler, A.: vide Nitsan, Zafrira

VI

Index

Goldman, J. K.: Effects of Intermittent Feeding on Rat Adipose Tissue and

Diaphragm Metabolism 325

Gontzea, I. and Nicolau, Nadia: Tocopherolemia in Healthy Human Adults . . 349

Grauel, L.: vide Zamenhof, S.

Greenberg, L. D. and Wheeler, Priscilla : Influence of Fatty-Acid Composition of Infant

Formulas on the Development of Arteriosclerosis and on the Lipid Composition of Blood and

Tissues. II. Further Lipid Studies . . 100

Guisard, D.; Bigard, M. A. et Debry, G.: Etude de Гépuration plasmatique des

lipides chez des sujets atteints de cirrhose hépatique d'origine éthylique

avec ascite 193

Guisard, D.: vide Bach, A.

Guisard, D.: vide Poullain, B.

Hambraeus, L.: vide Forsum, Elisabeth

Havivi, E.: Effect of Calcium and Vitamin D on Fluoride Metabolism in the Rat 257 
Hellström, K.: vide Edgren, B.

Henderson, J.R.: vide Jourdan, M.H.

Hornstra, G.: Digestibility, Efficiency and other Metabolic Effects of Dietary

Rapeseed Oil in Rats 282

Hughes, R.E.: vide Hurley, R.J.

Hurley, R. J.; Jones, P. R., and Hughes, R. E.: The Uptake of Ascorbic Acid by

the Tissues of Ascorbic Acid-deficient Guinea-Pigs 136

Irsigler, K.: vide Zazgornik, J.

Jager, F. C.: Effect of Dietary Linoleic Acid and Selenium on the Requirement of Vitamin E in Ducklings 210

Jager, F. C.: Long-Term Dose-Response Effects of Vitamin E in Rats. Significance of the in vitro Haemolysis Test

Jones, P.R.: vide Hurley, R.J.

Jourdan, M.H.: The Effect of a Sucrose-Enriched Diet on the Metabolism of

Intravenously Administered Fructose in Baboons 28

Jourdan, M. H.: The Incorporation of Fructose and Glucose, Given Intravenously, Into the Serum Lipids of Baboons 339

Jourdan, M. H.; MacDonald, I., and Henderson, J. R.: The Effects of 14C Xylitol, Given Intravenously on the Serum-Glucose, Insulin and Lipid Con

centrations of Male and Female Baboons 92

Kari-Kari, B. P. B.: vide Bruckdorfer, K. R.

Khan, I.H.: vide Bruckdorfer, K.R.

Kim, I.: vide Anderson, T.A.

Kline, E.: vide Zazgornik, J.

Kryspin-Exner, K.: vide Zazgornik, J.

Kudlicka, V. and Rath, R.: Albumin Metabolism as a Function of Lean Body

Mass 83

Labrousse De Tregomain, B.: vide Gennes, J. L. De

Laporte, J.-C.: Action in vitro de $\Gamma$ éthanol sur les activités antitrypsique et

protéolytique du plasma et du serum 271

MacDonald, I.: vide Coles, Betty L.

MacDonald, I.: vide Jourdan, M.H.

Index VII

Mariani, A.: vide Ferro-Luzzi, Anna

Marthens, E. Van: vide Zamenhof, S.

Metais, P.: vide Bach, A.

Meyer-Bahlburg, H.F.L.: Pilot Studies on Stimulant Effects of Capsicum Spices 245

Migliaccio, P.A.: vide Ferro-Luzzi, Anna

Nicolau, Nadia: vide Gontzea, I.

Nitsan, Zafrira and Gertler, A.: Enzymatic Activities in the Intestinal Tract of

Chicks Receiving a Diet Supplemented with Trypsin Inhibitors from

Soybean and Egg White 371

Oomen, H. A.P.C.: Distribution of Nitrogen and Composition of Nitrogen Com

pounds in Food, Urine and Faeces in Habitual Consumers of Sweet

Potato and Taro 65

Poullain, B.; Guisard, D. et Debry, G.: Etude de Гinfluence des protéines 
texturées de soja sur le bilan azote de Thomme

Raetzer, H.: vide Schlierf, G.

Rath, R.: vide Kudlicka, V.

Saxena, S.C.; Vendelmans-Starrenburg, A., and Vles, R.O.: Effects of Feeding

Medium Chain Triglycerides to Rats for 13 Weeks 362

Schlierf, G. and Raetzer, H.: Diurnal Patterns of Blood Sugar, Plasma Insulin, Free Fatty Acid and Triglyceride Levels in Normal Subjects and in Patients with Type IV Hyperlipoproteinemia and the Effect of Meal Frequency 113

Sorrentino, Donatella : vide Ferro-Luzzi, Anna

Starrenburg, Anna : vide Abdellatif, A. M. M.

Stavem, P.: vide Andersen, H. T.

Thomopoulos, P.: vide Gennes, J. L. De

Truffert, J.: vide Gennes, J. L. De

Vendelmans-Starrenburg, A.: vide Saxena, S. C.

Vles, R.O.: vide Abdellatif, A. M.

Vles, R.O.: vide Saxena, S.C.

Walker, B. L.: Deposition of Erucic Acid in Rat Tissue Lipids

Wheeler, Priscilla: vide Greenberg, L.D.

Yudkin, J.: vide Bruckdorfer, K.R.

Zamenhof, S.; Marthens, E. Van, and Grauel, L.: DNA (Cell Number) and

Protein in Rat Brain. Second Generation (F2) Alteration by Maternal

(F0) Dietary Protein Restriction 262

Zazgornik, J.; Irsigler, K.; Kline, E., and Kryspin-Exner, K.: The Eccrine

Sweat-Gland Function of Chronic Alcoholics 307

Book Reviews - Buchbesprechungen - Livres nouveaux . . . 63,127,191,255,324

Varia ., 128

Vol. 14, Supplement Complete Intravenous Nutrition

Symposium held at the 10th Meeting of the Group of European Nutritionists in Saltsjöbaden,

June 1971

Wretlind, A.: Complete Intravenous Nutrition. Theoretical and Experimental

Background 1

Heuckenkamp, P.-U. and Zöllner, N.: The Comparative Metabolism of Carbo

hydrates Administered Intravenously 58

Eklund, J.; Granberg, P.-O., and Hallberg, D.: Clinical Aspects of Body Fluid

Osmolality 74

Cuthbertson, D.P.; Fell, G.S.; Smith, CM., and Tilstone, W.J.: Nutrition in

the Post-Traumatic Period 92

Liljedahl, S. O. and Birke, G.: The Nutrition of Patients with Extensive Burns . 110

Børresen, H. C.: Balanced Intravenous Nutrition in Pediatric Surgery 114

Bergström, K.; Blomstrand, R. and Jacobson, S.: Long-Term Complete Intra venous Nutrition in Man 118

Jacobson, S.: Long-Term Parenteral Nutrition Following Massive Intestinal

Resection $\quad 150$

Bergström, J.; Fürst, P.; Josephson, B., and Norée, L.-O.: Factors Affecting the

Nitrogen Balance in Chronic Uremic Patients Receiving Essential Amino

Acids Intravenously or by Mouth 162 